\title{
Correction to: Mass strandings of seven toothed and baleen whale species in Northern Norway in March 2020 call for further investigation
}

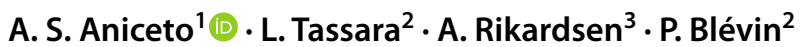

Published online: 14 June 2021

(c) The Author(s) 2021

\section{Correction to: Polar Biology https://doi.org/10.1007/s00300-021-02869-6}

Unfortunately, the original publication of the article has been published with errors in the title, first and second author's affiliation.

The correct title and affiliation are given in this correction. The original article has been corrected.

Open Access This article is licensed under a Creative Commons Attribution 4.0 International License, which permits use, sharing, adaptation, distribution and reproduction in any medium or format, as long as you give appropriate credit to the original author(s) and the source, provide a link to the Creative Commons licence, and indicate if changes were made. The images or other third party material in this article are included in the article's Creative Commons licence, unless indicated otherwise in a credit line to the material. If material is not included in the article's Creative Commons licence and your intended use is not permitted by statutory regulation or exceeds the permitted use, you will need to obtain permission directly from the copyright holder. To view a copy of this licence, visit http://creativecommons.org/licenses/by/4.0/.

Publisher's Note Springer Nature remains neutral with regard to jurisdictional claims in published maps and institutional affiliations.
The original article can be found online at https://doi.org/10.1007/ s00300-021-02869-6.

\section{A. S. Aniceto}

ana.s.aniceto@uit.no

1 Department of Fisheries and Bioeconomics, Arctic University of Norway, Troms $\emptyset$, Norway

2 Akvaplan Niva AS, Fram Centre, NO-9296 Troms $\varnothing$, Norway

3 Department of Arctic Biology, Arctic University of Norway, Troms $\emptyset$, Norway 